\title{
Genetic diversity analysis and phylogenetic reconstruction of groupers Epinephelus spp. from Madura Island, Indonesia based on partial sequence of CO1 gene
}

\author{
ABDUL BASITH ${ }^{1, \vartheta}$, ABINAWANTO $^{2, v v}$, ENI KUSRINI $^{3}$, YASMAN $^{2}$ \\ ${ }^{1}$ Doctoral Program of Biology, Department of Biology, Faculty of Mathematics and Natural Sciences, Universitas Indonesia. Jl. Lingkar UI, Depok \\ 16242, West Java, Indonesia. •email: golden_bee46@yahoo.com \\ ${ }^{2}$ Department of Biology, Faculty of Mathematics and Natural Sciences, Universitas Indonesia. Jl. Lingkar UI, Depok 16242, West Java, Indonesia. \\ Tel.: +62-21-7270163, 78849009, Fax.: +62-21-78849010, ${ }^{* e m a i l: ~ a b i n a w a n t o . m s @ s c i . u i . a c . i d ~}$ \\ ${ }^{3}$ Research and Development Institute for Ornamental Fish Culture. Jl. Perikanan No. 13, Pancoran Mas, Depok 16436, West Java, Indonesia
}

Manuscript received: 6 September 2021. Revision accepted: 21 September 2021.

\begin{abstract}
Basith A, Abinawanto, Kusrini E, Yasman. 2021. Genetic diversity analysis and phylogenetic reconstruction of groupers Epinephelus spp. from Madura Island, Indonesia based on partial sequence of CO1 gene. Biodiversitas 22: 4282-4290. Groupers populations in Indonesia, particularly from Madura Island, East Java are indicated to be over-fished, thereby requiring data collection of more accurate genetic resources as an important step for grouper conservation. A total of 14 samples of the Epinepheplus groupers were obtained from the fish landing port on Madura Island. The $617 \mathrm{bp} \mathrm{CO1}$ gene sequence was utilized for genetic diversity analysis and phylogenetic tree reconstruction. Genetic diversity is based on the value of haplotype diversity (Hd) and nucleotide diversity $(\pi)$. Reconstruction of the phylogenetic tree includes neighbor-joining (NJ) implementing K2P substitution model, while maximum likelihood (ML) is conducted by implementing HKY $+\mathrm{G}+\mathrm{I}$ substitution model, both of which were evaluated by employing a bootstrap of 1000 replications. Analysis of genetic distance between species indicated that the farthest distance between E. heniochus and E. fasciatus was 0.189 , while the closest distance between E. erythrurus and E. ongus was 0.099 . Intrapopulation genetic diversity indicated a high value with details of $\mathrm{Hd}=0.978$ and $\pi=0.12107$. Furthermore, NJ and ML phylogenetic tree demonstrated similar topology in the observed Epinephelus spp. obtained from Madura Island grouped into 7 clades, that is Epinephelus coioides, E. bleekeri, E. areolatus, E. erythrurus, E. heniochus, E. fasciatus, and E. ongus.
\end{abstract}

Keywords: Cytochrome c oxidase 1, DNA barcoding, genetic diversity, groupers species, phylogenetic

\section{INTRODUCTION}

Indonesia is acknowledged as one of the largest producers of reef fish trade worldwide, especially for grouper contributing $26.5 \%$ of the global capture production (Muldoon et al. 2016; Amorim et al. 2020). The high intensity of fishing has been due to the increasing demand for grouper, serving as an important economic commodity (Khasanah et al. 2019). Particularly, Madura Island is one of the potential grouper producers in East Java, Indonesia, generating 159.8 tons within 1179,166 fishing trips every fishing season (Sukandar et al. 2016). Status of sustainable management of fishery resources in the Madura Strait based on 5 dimensions of observation concludes that the sustainability scores for the ecological, economic dimensions and technology are $<50$ with status less sustainable (Hidayah et al. 2020).

Grouper in Indonesian waters is grouped into various genera, one of which is Epinephelus. The Epinephelus Bloch genus was placed under the subfamily of Epinephelinae in 1973, as one of three subfamilies in the family Serranidae, commonly acknowledged as groupers, rockcods, and seabasses (Heemstra and Randall 1993). Grouper identification based on morphological characters has been ambiguous leading to misidentification due to similarity in color and morphology, requiring accurate identification for conservation management through molecular approach (Ma et al. 2016; Kline et al. 2011; Kamal et al. 2019).

The literature development of DNA barcoding indicates that a short fragment of CO1 could be utilized as an accurate marker of genetic variation to identify a wide range of animals at the species level. Becker et al. (2011) provide an overview of the progress of DNA barcoding applications according to taxonomy and geographic area. Approximately, 31.000 species of fish are currently known, $25 \%$ of which has been successfully processed, with at least one species from $89 \%$ of all families barcoded. Furthermore, Hanner et al. (2011) although currently less than 30.000 species are recognized and there is still species that need to be re-evaluated, new species are routinely discovered. Accurate assessment of species diversity has always been a major challenge for ichthyology biosystematics, especially the fact that morphological shifts that are almost always found throughout the developmental stage of the species, and sometimes sex, and perhaps more subtle shifts across geographic ranges. Imtiaz et al. (2017) explained that DNA barcoding has a high potential to identify species, resolve ambiguities in species identification, and assist in accurate species identification.

Molecular approaches using DNA barcodes have been widely preferred to identify groupers, especially in 
selecting cytochrome c oxidase subunit 1 (CO1) gene sequence. Reports on the identification of grouper species, particularly Epinephelus spp., based on partial sequence of $\mathrm{CO} 1$ gene in various water areas continue to grow, some of which were in the Phillippines (Alcantara and Yambot 2016), Vietnam (Durand et al. 2020), Malaysia (Aziz et al. 2016; Du et al. 2019), Thailand (Noikotr et al. 2013), China (Qu et al. 2018), India (Basheer et al. 2017; Deepti et al. 2018), Saudi Arabia (Trivedi et al. 2014) and the Great Barrier Reef of Australia (Johnson and Wilmer 2019). In more circumstances, the complete mitochondrial genome of some groupers has been successfully sequenced, such as Epinephelus quoyanus (Peng et al. 2014) and Epinephelus awoara (Qu et al. 2012).

Meanwhile in Indonesia, the application of partial sequence of $\mathrm{CO} 1$ gene in several grouper species has generally been reported by Jefri et al. (2015) at distant sampling points, in Lampung, Karimunjawa, Madura, Lombok, Tanakeke, Kendari, and Numfor. In addition, grouper sampling at more specific locations was also reported, some of which were in Aceh (Kamal et al. 2019), Pangandaran West Java (Ariyanti and Farajallah 2019), and West Papua (Tapilatu et al. 2021). Then to complement previous research, this study focuses on observing the genetic diversity and reconstructing the phylogenetic tree of various grouper types (Epinephelus spp.) found on Madura Island, East Java, Indonesia. The results of this study are expected to complement the identification results of grouper on Madura Island by utilizing a morphological approach (Basith et al. 2021), comprehensively providing important information, required for the development of management and conservation policies regarding the declining numbers of various grouper species on Madura Island.

\section{MATERIALS AND METHODS}

\section{Sample collection}

The sampling locations of groupers Epinephelus spp. from Madura Island, East Java Province, Indonesia are presented in Figure 1, containing the coordinate details of fish landing ports, which are: Banyu Sangkah (6 ${ }^{\circ} 52^{\prime} 59.42^{\prime}$ " S-113 $1^{\circ} 45.58^{\prime \prime}$ E), Ketapang (6 ${ }^{\circ} 53^{\prime} 31.27^{\prime}$ 'S-113 $16^{\prime} 47.95^{\prime \prime}$ E), Ambunten (6 ${ }^{\circ} 53^{\prime} 16.82^{\prime}$ S- S-113 44'17.68 E), Dungkek (6 58'45.36" S-114 5'56.12" E), Camplong (7¹3'4.61" S$113^{\circ} 20^{\prime 2} 28.83^{\prime \prime}$ E), Branta Pasisir (7¹3'26.38” S-113²6'55.41" E), and Prenduan ( $7^{\circ} 6^{\prime} 34.52^{\prime \prime}$ S-113 $40^{\prime} 35.55^{\prime \prime}$ E). Samples were collected from March to October 2019 from fishermen's catches at Fish Landing Ports on Madura Island, by ensuring that the grouper was obtained from the waters around the observed area.

The FAO species catalog Vol. 16 Groupers of the world (Serranidae family, Subfamily Epinephelinae) (Heemstra and Randall, 1993) have been applied as a reference to analyze the morphological characteristics of groupers in this study. Based on the morphological characteristics, grouper fish samples were grouped into Epinephelus coioides, E. bleekeri, E. areolatus, E. heniochus, E. erythrurus, E. fasciatus and E. ongus. The grouper samples were undertaken with a pectoral fin of 15-20 grams for preservation in absolute ethanol (96\%), further prepared for molecular analysis. Molecular analysis was conducted at the Research and Genetics Laboratory, in State Islamic University of Malang, Indonesia.

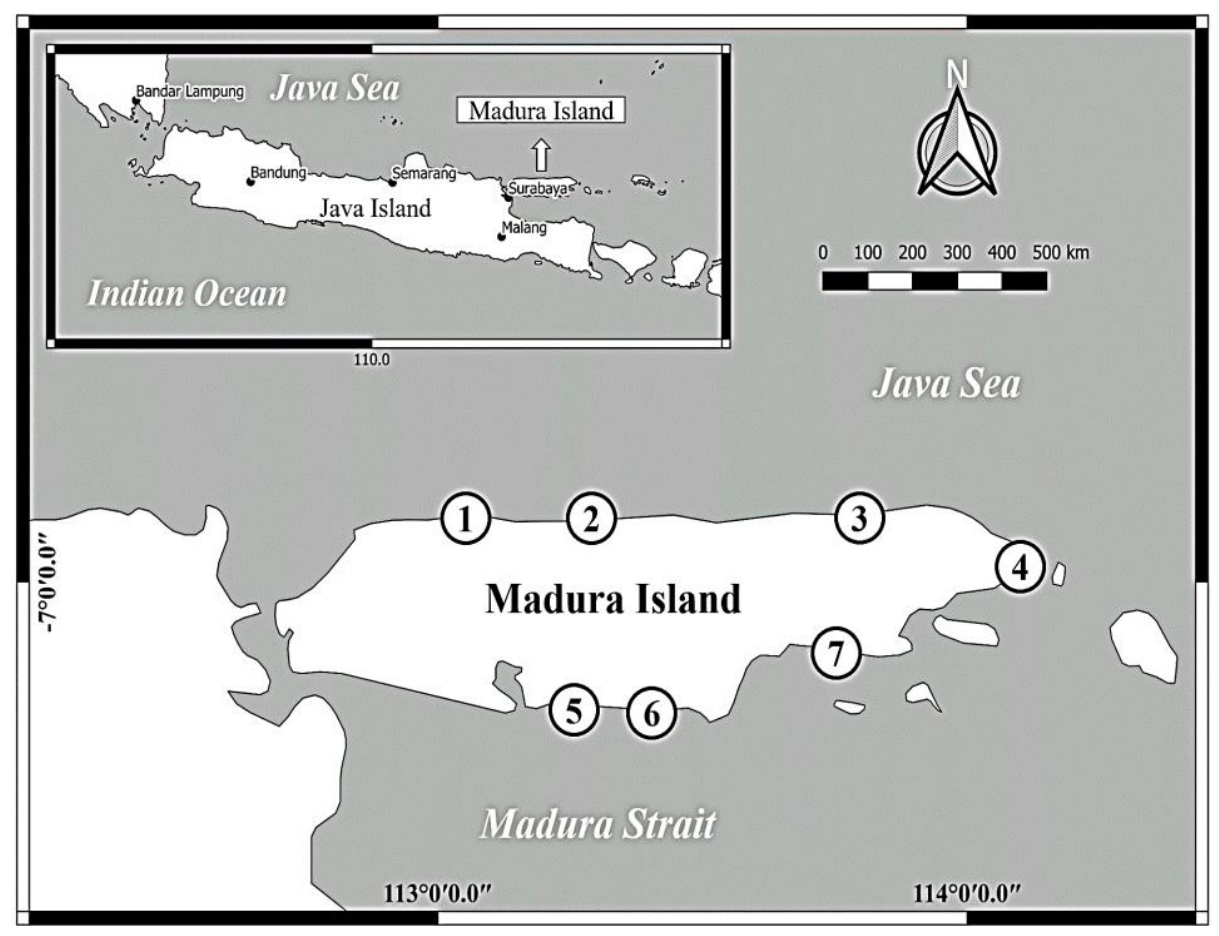

Figure 1. Map of Madura Island, East Java, Indonesia and the position of survey location for fishing ports, comprising: 1. Banyu Sangkah (BNS), 2. Ketapang (KTP), 3. Ambunten (AMB), 4. Dungkek (DGK), 5. Camplong (CMP), 6. Branta Pasisir (BRP), and 7. Prenduan (PRD) 


\section{DNA extraction and PCR reaction}

Grouper fin samples that preserved in absolute ethanol were first washed using aquadest and TE buffer, then crushed manually by adding liquid nitrogen. Extraction of total DNA in this research sample was performed through the Wizard ${ }^{\circledR}$ Genomic DNA Purification Kit (Promega Corporation) by following the protocol. The universal primer for partial sequence of CO1 gene for PCR was developed by Ward et al. (2005) with forward primer sequence of Fish F1 5'-TCAACCAACCACAAAGACA TTGGCAC-3' and reverse sequence of Fish R1 5'TAGACTTCTGGGTGGCCAAAGAATCA-3'. PCR amplification was performed with MyTaq HS Red Mix (Bioline) with composition details of $9.5 \mu \mathrm{L}$ ddH2O, 12.5 $\mu \mathrm{L}$ MyTaq HS Red Mix, $1 \mu \mathrm{L} 10 \mathrm{M}$ forward primer (Fish F1), $1 \mu \mathrm{L} 10 \mathrm{M}$ reverse primer (Fish R1), and $1 \mu \mathrm{L}$ sample DNA template.

The PCR cycles were sequentially initiated with predenaturation at $95^{\circ} \mathrm{C}\left(1\right.$ minute), denaturation at $96^{\circ} \mathrm{C}$ (15 seconds), annealing of $\mathrm{CO} 1$ primer at $55^{\circ} \mathrm{C}(30$ seconds), elongation of target genes at $72^{\circ} \mathrm{C}$ (45 seconds), and finalized by maintaining $4^{\circ} \mathrm{C}$ until the PCR product was utilized. The main amplification parts (denaturation, annealing, and elongation) were repeated for 35 cycles. The $\mathrm{CO} 1$ gene sequence amplicon was confirmed by using agarose gel electrophoresis with $1 \%$ agarose gel at a voltage of $100 \mathrm{~V}$ for 25 minutes, along with a comparison marker of 100 bp DNA ladder (Intron). Gene purification was performed through a gel extraction method with the standard protocol of GeneJET Gel Extraction and DNA cleanup Micro Kit (the thermo scientific). Meanwhile, nucleotide sequencing was carried out by the service of 1 st BASE (Singapore).

\section{Data analysis}

Sequences editing, validation, and alignment

Partial sequence of $\mathrm{CO} 1$ gene along 600-700 bp were obtained from 14 groupers of Epinephelus spp. from Madura Island. Each sequence was initially translated into an amino acid sequence to check and remove the stop codon in the middle of the sequence (Song et al. 2008). Sequence examination and editing were conducted by applying the BioEdit software (Hall 1999), in addition to manual careful examination. Each sequence sample was validated by using online facility the Basic Local Alignment Search Tool (BLAST) of GenBank/NCBI and the Barcode of Life Data System (BOLD System). A total of 16 accessions from GenBank (NCBI) were selected as in group and out group for the phylogenetic tree reconstruction. Multiple sequences alignment was performed by using the ClustalW algorithm (Thompson et al. 1994) in MEGA X software version 10.2.6. (Kumar et al. 2018).

\section{Sequence composition, genetic diversity and genetic distance}

Analysis of intrapopulation genetic diversity based on partial sequence of $\mathrm{CO} 1$ gene in 14 groupers of Epinephelus spp. from Madura Island was performed with DnaSP software version 6.12.03 (Rozas et al. 2017). Information on genetic diversity was analyzed through items, such as: the value of nucleotide diversity $(\pi)$, the number of polymorphic sites (S), the haplotype analysis (haplotype diversity (Hd), the number of haplotypes (nHap), and the variance of haplotype diversity (Nei 1987). In addition, MEGA $\mathrm{X}$ software version 10.2.6 was employed to calculate the nucleotide frequencies, transition/ transversion rate ratio $(\mathrm{k})$, transition/transversion rate ratio bias $(\mathrm{R})$, and probability and pattern of nucleotide substitution by applying the maximum composite likelihood method. The estimated value of the Gamma Distribution was calculated by using the $\mathrm{HKY}+\mathrm{G}$ substitution model (Hasegawa et al. 1985) with complete deletion options for gaps and missing data. Genetic distance analysis between species was conducted on the 7 validated species of Epinephelus spp. obtained from Madura Island. Genetic distance calculation was performed by using the maximum composite likelihood method with a bootstrap of 1000 replications (Felsenstein 1985).

\section{Phylogenetic tree reconstruction}

Reconstruction of the phylogenetic tree based on partial sequence of $\mathrm{CO} 1$ gene was conducted on a total of 30 sequences (included in group and out group accessions obtained from GenBank). Reconstruction of phylogenetic tree was performed by using MEGA X version 10.2.6. Meanwhile, the applied methods for phylogenetic tree reconstruction were Neighbor-Joining (NJ) and MaximumLikelihood (ML). NJ reconstruction was calculated by using K2P substitution model (Kimura 2-Parameter) (Kimura, 1980), Gamma Distribution (G), and pairwise deletion gaps/missing data treatment. Meanwhile, ML reconstruction was performed through Hasegawa-KishinoYano+Gamma Distributed with Invariant $(\mathrm{HKY}+\mathrm{G}+\mathrm{I})$ substitution model, based on the best-fit substitution model using the BIC (Bayesian Information Criterion) and AICc (Akaike Information Criterion corrected) values (Hasegawa et al. 1985; Nei and Kumar 2000). Both of phylogenetic trees were evaluated by employing a bootstrap of 1000 replications (Felsenstein 1985).

\section{RESULTS AND DISCUSSION}

\section{PCR product visualization and sequence validation}

The PCR product visualized using $1 \%$ agarose gel electrophoresis indicated partial sequence of $\mathrm{CO} 1$ gene in 14 species of Epinephelus spp. grouper on Madura Island, was successfully amplified at 650-700 bp long (Figure 2), according to Ward et al. (2005), affirming that the CO1 universal primer produced an amplicon of $655 \mathrm{bp}$. Upon the completion process of multiple sequences alignment and minor editing, the sequence length that was employed in this study with an amplicon of $612 \mathrm{bp}$; in contrast to other previous studies by Jefri et al. (2015) using a 526 bp sequence, Basheer et al. (2017) using a $655 \mathrm{bp}$, and Tapilatu et al. (2021) using a $623 \mathrm{bp}$ in their respective analyses. Sequence validation results conducted through the online facility of BLAST (NCBI) and the BOLD system indicated that the sequence samples matched the available accessions in the database with query cover in the range of $97-100 \%$ (Table 1). 
The validation results depicted that the 14 samples were grouped into 7 species, including: E. coioides, E. bleekeri, E. areolatus, E. heniochus, E. ongus, E. erythrurus and E. fasciatus. In accordance with the results of the sequence validation, the similarity of the sequences reported by Jefri et al. (2015) was in the range of $99-100 \%$ and Tapilatu et al (2021) was in the range of $98-100 \%$. All species of Epinephelus spp. in this study are species that are commonly found in the waters of the Western Indo-Pacific, especially in Indonesian waters, according to the geographical distribution illustrated by Heemstra and Randall (1993). Specifically, the findings of E. areolatus in this study were in accordance with the findings in two samples of E. areolatus from Madura Island reported by Jefri et al. (2015).

\section{Sequence composition and genetic diversity}

The nucleotide composition of partial sequence of $\mathrm{CO} 1$ gene of Epinephelus spp. indicated that percentage figures were in accordance with the Teleosts reported by Ward et al. (2005). Percentage of bases (G, C, A, and T) in Epinephelus spp., respectively were $17.69 \%$, 29.37\%, $23.88 \%$, and $29.06 \%$, while the percentage of bases in Teleost was $18.31 \%, 28.75 \%, 23.58 \%$, and $29.38 \%$. Furthermore, the percentage of $\mathrm{G}+\mathrm{C}$ content in partial sequence of CO1 gene of Epinephelus spp. was $47.06 \%$, while on Teleost was $47.1 \%$, thereby indicating that the universal primer for partial sequence of CO1 gene developed by Ward et al. (2005) was conducted through accurate calculations, successfully applied in Epinephelus spp. groupers. The details of the genetic diversity analysis are summarized in Table 2.

Table 2. Summary analysis of intrapopulation genetic diversity based on partial sequence of $\mathrm{CO} 1$ gene of Epinephelus spp. obtained from Madura Island, East Java Province, Indonesia

\begin{tabular}{ll}
\hline Parameter & Analysis result \\
\hline Nucleotide frequencies & $23.88 \%$ \\
Adenine (A) & $29.06 \%$ \\
Thymine (T) & $29.37 \%$ \\
Cytosine (C) & $17.69 \%$ \\
Guanine $(\mathrm{G})$ & $47.06 \%$ \\
G+C content & 4.73 (purines) \\
Transition/transversion rate ratios (k) & 6256 (pyrimidines) \\
& 3.021 \\
transition/transversion bias (R) & 0.12107 \\
Nucleotide diversity $(\pi)$ & 141 \\
Number of polymorphic sites (S) & 0.978 \\
Haplotype diversity (Hd) & 12 \\
Number of haplotypes (nHap) & 0.00119 \\
Variance of haplotype diversity & 0.12018 \\
Gamma distribution & \\
\hline
\end{tabular}

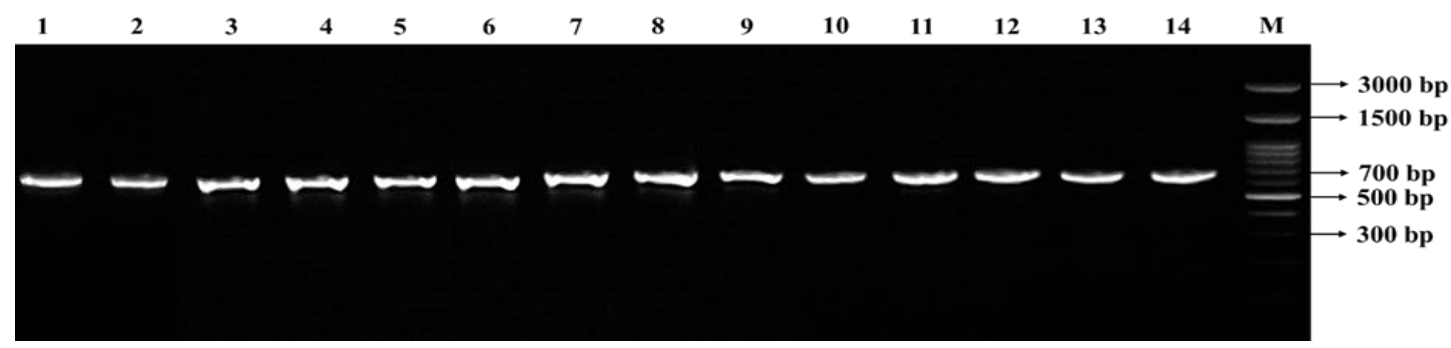

Figure 2. Amplicon visualization of partial sequence of CO1 gene of Epinephelus spp. obtained from Madura Island, East Java Province, Indonesia on 1\% gel electrophoresis. Note: M: DNA ladder 100 bp, 1: MDR-CMP103, 2: MDR-CMP105, 3: MDR-CMP207, 4: MDR-CMP208, 5: MDR-CMP209, 6: MDR-KTP011, 7: MDR-AMB013 , 8: MDR-AMB014, 9: MDR-BRP016, 10: MDR-BNS022, 11: MDR-BNS023, 12: MDR-PRD224, 13: MDR-DGK026, 14: MDR-DGK027

Table 1. Validation of partial sequence of CO1 gene of Epinephelus spp. obtained from Madura Island, East Java Province, Indonesia through the BLAST (GenBank/NCBI) and the BOLD System online facilities

\begin{tabular}{llcccc}
\hline \multirow{2}{*}{ Local accession number } & \multicolumn{1}{c}{ Species } & \multicolumn{2}{c}{ GenBank (NCBI) } & \multicolumn{2}{c}{ BOLD system } \\
\cline { 2 - 6 } MDR-CMP207 & Euery cover (\%) & E-value & \% identity & Similarity (\%) \\
\hline MDR-KTP011 & E. coioides & 97 & 0 & 99.5 & 100 \\
MDR-AMB013 & E. coioides & 97 & 0 & 96.9 & 100 \\
MDR-BRP016 & E. coioides & 100 & 0 & 98 & 100 \\
MDR-PRD224 & E. coioides & 100 & 0 & 96 & 99 \\
MDR-CMP208 & E. bleekeri & 98 & 0 & 97.8 & 99 \\
MDR-AMB014 & E. bleekeri & 97 & 0 & 99.8 & 99 \\
MDR-DGK026 & E. areolatus & 98 & 0 & 98 & 100 \\
MDR-DGK027 & E. areolatus & 99 & 0 & 98.5 & 100 \\
MDR-BNS022 & E. erythrurus & 98 & 0 & 97.4 & 99 \\
MDR-BNS023 & E. erythrurus & 98 & 0 & 96.5 & 100 \\
MDR-CMP209 & E. heniochus & 98 & 0 & 97.2 & 100 \\
MDR-CMP103 & E. fasciatus & 99 & 0 & 96.9 & 100 \\
MDR-CMP105 & E. ongus & 99 & 0 & 00 & 100 \\
\hline
\end{tabular}


Based on the value of haplotype diversity (Hd) 0.978 with nucleotide diversity $(\pi) 0.12107$, it is concluded that the genetic diversity of Epinephelus spp. grouper was relatively high. The diversity value was not much different from Basheer et al. (2017) with Hd value of 0.9830 and $\pi$ value of 0.14465 . Genetic diversity refers to the interpretation result of isolation ecologically, behaviorally and physically, comprising the limited number of individuals and selecting certain traits (Mignon-Grasteau et al. 2005). Populations with high genetic diversity have a better chance of survival, in which high value of genetic diversity illustrates that the population of Epinephelus spp. on Madura Island was in good condition, further indicating high chance of survival and adaptation to environmental quality disturbances including over-fishing pressure. However, this study consisted of multiple species, thereby encouraging future research specifically observing the genetic diversity of each Epinephelus spp. species.

Genetic diversity is influenced by distribution and habitat. Further, Crandall et al. (2008) explained that the widely marine biota, could have high genetic variation. In addition, habitat characteristics determine the genetic diversity of groupers, as revealed by Madduppa et al. (2012) indicating that the genetic diversity of the groupers that live on the slopes of coral reefs are higher than those living on the lagoons. Complementing the expression, Manel et al. (2020) systematically revealed that habitat complexity drives genetic diversity of marine fish, especially temperatures found at sea level, thereby explaining the high genetic diversity in demersal fish (less than 200 meters deep).

\section{Genetic distance and phylogenetic tree}

Genetic distance refers to the ratio of genetic differences between species or populations (Dogan and Dogan 2016). Based on the genetic distance matrix of 7 species of Epinephelus spp. groupers obtained in Madura Island, the closest distance is found between E. ongus and E. erythrurus with a value of 0.099 . In contrast, the farthest distance is navigated between E. fasciatus and E. heniochus with a value of 0.189 (Table 3 ). Thus, a smaller genetic distance value generates a more similar appearance partial sequence of $\mathrm{CO} 1$ gene compared between the two species.
Based on the standards from Nei (1972), the genetic distance of Epinephelus spp. grouper obtained in Madura Island is categorized into low (0.01-0.09) and medium (0.10.99), generally similar to Epinephelus spp. genetic distance calculations reported by Jefri et al. (2015). The value of genetic distance proved that the partial sequence of $\mathrm{CO} 1$ gene provides a fast and effective DNA barcode technique for species identification, especially in addressing morphological confusion or ambiguity, in line with the report of Noikotr et al. (2013). Furthermore, Madduppa et al. (2012) assumed that the lifestyle of Epinephelus spp. was classified as a limited, solitary, sedentary and territorial distribution in coral reef ecosystems indicating less different genetic distance.

A total of 16 accessions were downloaded from GenBank (NCBI) as in in-group and out-group access for reconstruction of phylogenetic tree of Epinephelus spp. (Table 4). Reconstruction of NJ and ML phylogenetic trees indicates similar topology in all samples of Epinephelus spp., restrictedly grouped into 7 species, in line with the results of validation applying the BLAST (NCBI) and BOLD system (Table 1) and in line with the calculation of genetic distance between species (Table 3). The phylogenetic tree of Epinephelus spp. in both NJ and ML, forms a clear and unambiguous branching pattern (Figures 3 and 4). This robust reconstruction of the phylogenetic tree is in line with previous study (Jefri et al. 2015).

The two phylogenetic trees indicate that E. ongus and E. erythrurus species form their own monophyletic branches; however, since the two species are connected at the same node, the formed branches formed indicated closeness. The branching position is in line with the calculation of the genetic distance of 0.099 , indicating the closeness between E. ongus and E. erythrurus. Moreover, Jefri et al. (2015) reported that the closest genetic distance was also found between E. ongus and E. coeruleopunctatus with a value of 0.091. In addition, Heemstra and Randall (1993) explained that E. ongus and E. erythrurus each had a maximum length of $40 \mathrm{~cm}$ and $45 \mathrm{~cm}$, indicating that the total length of the two was not much different. Furthermore, E. ongus has the opportunity to be misidentified with E. coeruleopunctatus, E. summana and E. corrallicola.

Table 3. Pairwise genetic distance matrix of the 7 species of Epinephelus spp. obtained in Madura Island, East Java Province, Indonesia

\begin{tabular}{clccccccc}
\hline No. & \multicolumn{1}{c}{ Species } & $\mathbf{1}$ & $\mathbf{2}$ & $\mathbf{3}$ & $\mathbf{4}$ & $\mathbf{5}$ & $\mathbf{6}$ & $\mathbf{7}$ \\
\hline 1. & Epinephelus coioides & - & $*$ & $*$ & $*$ & $*$ & $*$ & $*$ \\
2. & E. bleekeri & 0.149 & - & $*$ & $*$ & $*$ & $*$ & $*$ \\
3. & E. areolatus & 0.169 & 0.116 & - & $*$ & $*$ & $*$ & $*$ \\
4. & E. erythrurus & 0.121 & 0.130 & 0.137 & - & $*$ & $*$ & $*$ \\
5. & E. heniochus & 0.135 & 0.164 & 0.17 & 0.146 & - & $*$ & $*$ \\
6. & E. fasciatus & 0.155 & 0.145 & 0.153 & 0.151 & 0.189 & - & $*$ \\
7. & E. ongus & 0.133 & 0.160 & 0.170 & 0.099 & 0.150 & 0.182 & - \\
\hline
\end{tabular}


Table 4. List of species accessions of in group and out group obtained from GenBank (NCBI)

\begin{tabular}{|c|c|c|}
\hline Species & Locality & Accession \\
\hline \multicolumn{3}{|l|}{ In group accessions } \\
\hline \multirow[t]{2}{*}{ Epinephelus coioides } & Bali, Indonesia & GU673873 \\
\hline & Vietnam & MN708905 \\
\hline \multirow[t]{2}{*}{ E. bleekeri } & West Java, Indonesia & JN312976 \\
\hline & Vietnamese & MN708863 \\
\hline \multirow{2}{*}{ E. areolatus } & Maluku, Indonesia & MN870146 \\
\hline & Vietnam & MN708846 \\
\hline \multirow{2}{*}{ E. erythrurus } & West Java, Indonesia & KP998441 \\
\hline & Vietnam & MN708911 \\
\hline \multirow{2}{*}{ E. heniochus } & Bali, Indonesia & GU673833 \\
\hline & Malaysia & JN208617 \\
\hline \multirow{2}{*}{ E. fasciatus } & Maluku, Indonesia & MN870296 \\
\hline & Philippines & KJ130969 \\
\hline \multirow[t]{2}{*}{ E. ongus } & Maluku, Indonesia & MN870143 \\
\hline & India & JX675019 \\
\hline \multicolumn{3}{|l|}{ Out group accessions } \\
\hline Plectropomus maculatus & Bali, Indonesia & JN313061 \\
\hline P. maculatus & Philippiness & FJ583869 \\
\hline
\end{tabular}

The next closest genetic distance was found between $E$. areolatus and E. bleekeri with a value of 0.116 . Although according to Nei (1972) standard, the genetic distance of the two species is moderate, the branching of $\mathrm{NJ}$ and ML phylogenetic trees in both species indicated a close relationship at the same node. These two phylogenetic trees are in line with the previous study, conducted by Darwin et al. (2020) highlighting the proximity of the phylogenetic tree branching positions among E. areolatus, E. bleekeri, and E. chlorostigma. On the other hand, based on morphology, identification of E. areolatus presents a high chance of being misidentified as E. bleekeri and $E$. chlorostigma (Heemstra and Randall 1993; He et al. 2013).

The application of partial sequence of $\mathrm{CO} 1$ gene in this study indicates an accurate match between the genetic distance values and the phylogenetic tree, in which the combination of the two has been in accordance with the level of morphological similarity between Epinephelus spp. species, as found between E. ongus and E. erythrurus and between E. areolatus and E. bleekeri in this study. Thus, it is perceived that closer genetic distance equals to closer phylogenetic branching, indicating more similar morphology of Epinephelus spp., thereby generating misidentification. The conclusion regarding the suitability between the phylogenetic branching proximity and morphological similarities is in accordance with the study conducted by Tapilatu et al. (2021).

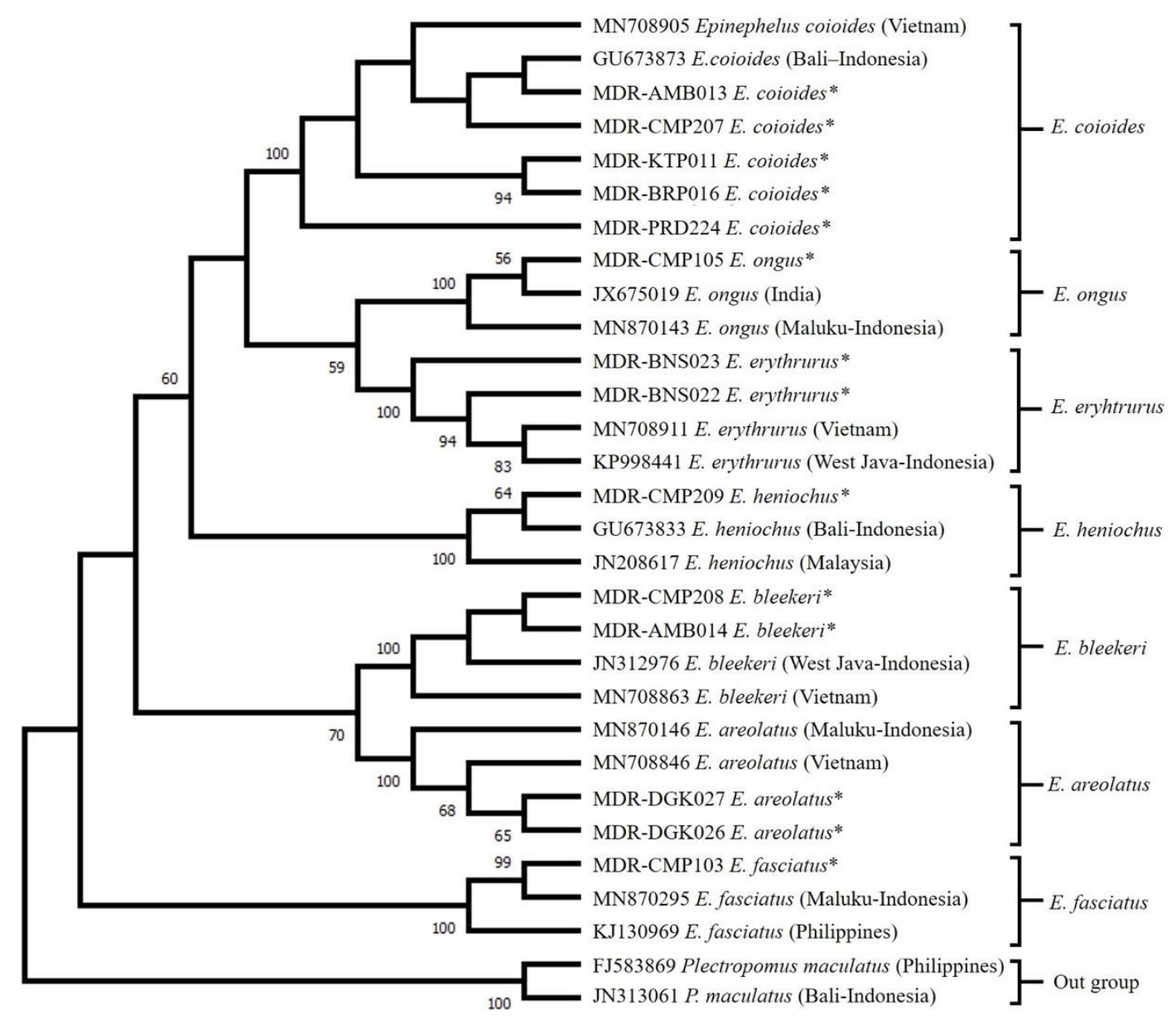

Figure 3. Neighbor-Joining (NJ) phylogenetic tree of Epinephelus spp. The asterisk (*) denotes the sequence of Epinephelus spp. obtained from Madura Island, East Java Province, Indonesia 


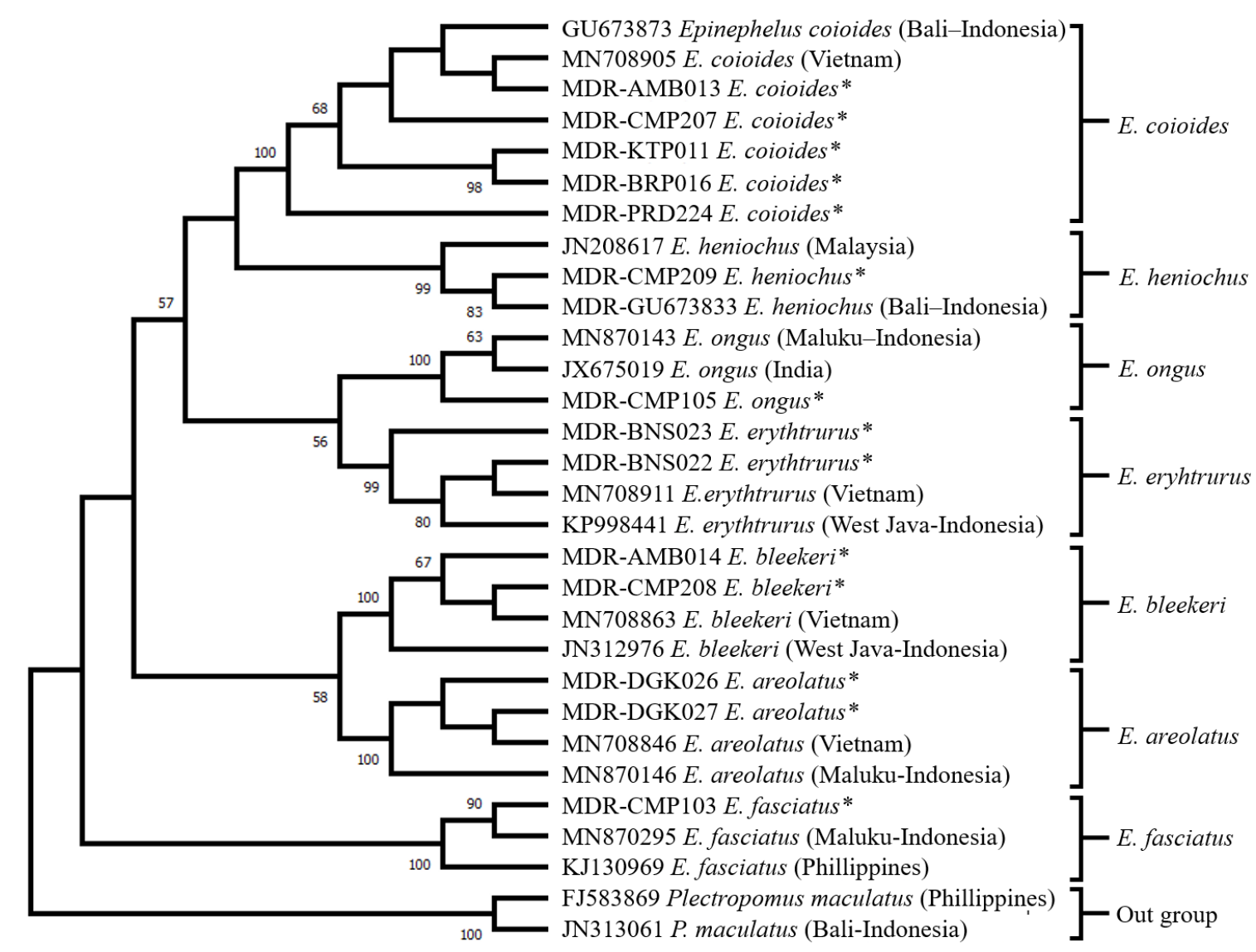

Figure 4. Maximum-Likelihood (ML) phylogenetic tree of Epinephelus spp. The asterisk (*) denotes the sequence of Epinephelus spp. obtained from Madura Island, East Java Province, Indonesia

Kamal et al. (2019) explained that grouper from Peukan Bada waters had been misidentified due to its morphological ambiguity, thereby requiring the application of partial sequence of $\mathrm{CO} 1$ gene for authentication. Previously, the potential misidentification of groupers had been reported by Heemstra and Randall (1993). This indicates a phenomenon of phenotypic plasticity in groupers, referring to the ability of one gene to produce more than one phenotype due to exposure to different environmental conditions (Kamal et al. 2019). Similarly, the phenomenon of phenotypic plasticity was observed in E. itajara and E. adscensionis, and possibility to occur in all grouper species (Craig et al. 2009; Kline et al. 2011).

Hence, this study becomes the first to report on the genetic diversity and phylogenetic reconstruction of Epinephelus spp. from the coastal area of Madura Island based on partial sequence of $\mathrm{CO} 1$ gene. Although the genetic diversity of grouper on Madura Island is relatively high, the decrease in diversity due to habitat destruction and over-fishing has been inevitable. The results of this study indicate that a molecular approach using the partial sequence of $\mathrm{CO} 1$ gene supports the identification results based on a morphological approach in Epinephelus spp. found in Madura Island, and soon will be submitted to the GenBank (NCBI) database. Future research is encouraged to emphasize the integration of molecular and morphological approaches to improve the resolution of grouper species identification. Comprehensively, all the information collected will support the management of grouper fishery genetic resources management, especially in Madura waters.

\section{ACKNOWLEDGEMENTS}

The authors addressed their gratitude to all parties assisting the completion of this research, particularly the Genetics Laboratory, Department of Biology, University of Indonesia, Depok and Research and Molecular Laboratory, Faculty of Science and Technology, State Islamic University of Malang.

\section{REFERENCES}

Alcantara SG, Yambot AV 2016. DNA barcoding of commercially important grouper species (Perciformes, Serranidae) in the Philippines. Mitochondrial DNA A DNA Mapp Seq Anal 27 (6): 3837-3845. DOI: $10.3109 / 19401736.2014 .958672$

Amorim P, Sousa P, Jardim E, Azevedo M, Menezes GM. 2020. Lengthfrequency data approaches to evaluate snapper and grouper fisheries 
in the Java Sea, Indonesia. Fish Res 229: 1-15. DOI: 10.1016/j.fishres.2020.105576

Ariyanti Y, Farajallah A. 2019. Species confirmation of juvenile cloudy grouper, Epinephelus erythrurus (Valencinennes, 1828), based on morphological analysis and partial $\mathrm{CO} 1$ gene sequencing. Biodiversitas 20 (3): 914-921. DOI: 10.13057/biodiv/d200341

Aziz NMA, Esa Y, Arshad A. 2016. DNA barcoding and phylogenetic analysis of Malaysian grouper (Subfamily Epinephelinae) using mitochondrial cytochrome c oxidase I (COI) gene. J Environ Biol 37: 725-733.

Basheer VS, Vineesh N, Bineesh KK, Kumar RG, Mohitha C, Venu S, Kathirvelpandian A, Gopalakrishnan A, Jena JK. 2017. Mitochondrial signatures for identification of grouper species from Indian waters. Mitochondrial DNA Part A 28 (4): 451-457. DOI 10.3109/19401736.2015.1137899

Basith A, Abinawanto A, Kusrini E. Yasman Y. 2021. Species inventories and conservation status of groupers (family Serranidae) from Madura Island, East Java, Indonesia. AIP Conf Proc 2331: 050021. DOI: $10.1063 / 5.0042167$

Becker S, Hanner R, Steinke D. 2011. Five years of FISH-BOL: Brief status report. Mitochondrial DNA 22 (S1): 3-9. DOI: $10.3109 / 19401736.2010 .535528$

Craig MT, Graham RT, Torres RA, Hyde JR, Freitas MO, Ferreira BP, Hostim-Silva M, Gerhardinger LC, Bertoncini AA, Robertson DR. 2009. How many species of goliath grouper are there? Cryptic genetic divergence in a threatened marine fish and the resurrection of a geopolitical species. Endanger Species Res 7 (3): 167-174. DOI: 10.3354/esr00117

Crandall ED, Frey MA, Grosberg RK. Barber PH. 2008. Contrasting demographic history and phylogeographical patterns in two IndoPacific Gastropods. Mol Ecol 17: 611-626. DOI: 10.1111/j.1365294X.2007.03600.x

Darwin C, Pamulapati P, Gatreddi S. 2020. Taxonomic validation of Areolate grouper, Epinephelus areolatus (Perciformes: Serranidae) along the Nizampatnam coast, India. J Appl Biol Biotechnol 8 (4): 7 15. DOI: $10.7324 /$ jabb.2020.80402

Deepti VI, Kandula S, Khedkar GD. 2018. DNA barcoding of five species of groupers (Pisces: Serranidae) of Visakhapatnam, central eastern coast of India. Mitochondrial DNA Part A 29 (5): 659-663. DOI $10.1080 / 24701394.2017 .1339188$

Dogan I, Dogan N. 2016. Genetic distance measures: Review. Turkiye Klinikleri J Biostat 8 (1): 87-93. DOI: 10.5336/biostatic.2015-49517

Durand JD, Pham MH, Tran TTV, Hoang DH, Vo QV. 2020. Sorting the wheat from the chaff: A review of BINs associated with groupers of Vietnam and the implications for species identification from DNA barcoding. Mar Biodivers 50 (3): 1-23. DOI:10.1007/s12526-02001051-1

Felsenstein J. 1985. Confidence limits on phylogenies: An approach using the bootstrap. Evolution 39: 783-791. DOI: 10.1111/j.1558 5646.1985.tb00420.x

Hall TA 1999. BioEdit: A user-friendly biological sequence alignment editor and analysis program for Windows 95/98/NT. Nucleic Acids Symp Ser 41: 95-98.

Hanner R, Desalle R, Ward RD, Kolokotronis S-O. 2011. The Fish Barcode of Life (FISH-BOL) special issue. Mitochondrial DNA 22 (S1): 1-2. DOI: $10.3109 / 19401736.2011 .598767$

Hasegawa M, Kishino H, Yano T. 1985. Dating the human-ape split by a molecular clock of mitochondrial DNA. J Mol Evol 22: 160-174. DOI: $10.1007 / \mathrm{BF} 02101694$

He B, Lai T, Peng Z, Wang X, Pan L. 2013. Complete mitogenome of the areolate grouper Epinephelus areolatus (Serranidae, Epinephelinae). Mitochondrial DNA 24 (5): 498-500. DOI: 10.3109/19401736.2013.770503

Heemstra PC, Randall JE. 1993. FAO species catalogue. Vol.16. Groupers of the world (Family Serranidae, Subfamily Epinephelinae). An annotated and illustrated catalogue of the grouper, rockcod, hind, coral grouper and lyretail species known to date. Rome (IT): Food and Agriculture Organization of the United Nations.

Hidayah Z, Nuzula NI, Wiyanto DB. 2020. Sustainability Analysis of Fisheries Management in Madura Strait East Java. Jurnal Perikanan Universitas Gadjah Mada 22 (2): 101-111. DOI: 10.22146/jfs.53099 [Indonesian]

Imtiaz A, Mohd Nor SA, Naim DMD. 2017. Review: Progress and potential of DNA barcoding for species identification of fish species. Biodiversitas 18 (4): 1394-1405. DOI: 10.13057/biodiv/d180415
Jefri E, Zamani NP, Subhan B, Madduppa HH. 2015. Molecular phylogeny inferred from mitochondrial DNA of the Grouper Epinephelus spp. in Indonesia collected from local fish market. Biodiversitas 16 (2): 254-263. DOI: 10.13057/biodiv/d160221

Johnson JW, Wilmer JW. 2019. Epinephelus fuscomarginatus (Perciformes: Epinephelidae), a new species of grouper from off the Great Barrier Reef, Australia. Zootaxa 4674 (3): 329-348. DOI: 10.11646/zootaxa.4674.3.2

Kamal MM, Hakim AA, Butet NA, Fitrianingsih Y, Astuti R. 2019. Authentication of grouper species based on the MT-CO1 gene marker from Peukan Bada Waters, Aceh. J Trop Biol 19 (2): 116-123. DOI: 10.29303/jbt.v19i2.1245 [Indonesian]

Khasanah M, Nurdin N, Sadovy Y, Jompa J. 2019. Management of the grouper export trade in Indonesia. Rev Fish Sci Aquac 28: 1-15. DOI: $10.1080 / 23308249.2018 .1542420$

Kline RJ, Khan IA, Holt GJ. 2011. Behavior, color change and time for sexual inversion in the protogynous grouper (Epinephelus $\begin{array}{llllll}\text { adscensionis). } & \text { PLoS One } 6 & \text { (5): } & \text { e19576. } & \text { DOI: }\end{array}$ 10.1371/journal.pone.0019576

Ma KY, Craig MT, Choat JH, van Herwerden L. 2016. The historical biogeography of groupers: Clade diversification patterns and processes. Mol Phylogenet Evol 100: 21-30. DOI: 10.1016/j.ympev.2016.02.012

Madduppa HH, Agus SB, Farhan AR, Suhendra D, Subhan B. 2012. Fish biodiversity in coral reefs and lagoons at the Maratua Island, East Kalimantan. Biodiversitas 13: 145-150. DOI: $10.13057 /$ biodiv/d130308

Manel S, Guerin PE, Mouillot D, Blanchet S, Velez L, Albouy C, Pellissier L. 2020. Global determinants of freshwater and marine fish genetic diversity. Nat Comm 11 (692): 1-9. DOI: 10.1038/s41467020-14409-7

Mignon-Grasteau S, Boissy A, Bouix J, Faure JM, Fisher AD, Hinch GN, Jensen $\mathrm{P}$, Le Neindre $\mathrm{P}$, Mormède $\mathrm{P}$, Prunet $\mathrm{P}$, Vandeputte $\mathrm{M}$, Beaumont C. 2005. Genetics of adaptation and domestication in livestock. Livest Prod Sci 93 (1): 3-14. DOI: 10.1016/j.livprodsci.2004.11.001

Muldoon G, Sadovy YJ, Shea S, Tam I, Welford R, Whitfort A. 2016. Mostly legal, but not sustainable how airlines can support sustainable trade in live reef food fish. Hong Kong: ADM Capital Foundation Report.

Nei M, Kumar S. 2000. Molecular evolution and phylogenetics. Oxford University Press, New York.

Nei M. 1972. Genetic distance between populations. Am Nat 106: 283292.

Nei M. 1987. Molecular Evolutionary Genetics. Columbia University Press, New York.

Noikotr K, Chaveerach A, Pinthong K, Tanomtong A, Sudmoon R, Tanee T. 2013. RAPD and barcode analysis of groupers of the Genus Epinephelus. Genet Mol Res 12 (4): 5721-5732. DOI: 10.4238/2013.November.18.21

Peng Z, Chen J, Lai T, Huang Y, Wu L. 2014. Complete mitochondrial genome of the longfin grouper Epinephelus quoyanus (Serranidae: Epinephelinae). Mitochondrial DNA 25 (3): 175-176. DOI: 10.3109/19401736.2013.792063

Qu M, Tang W, Liu Q, Wang D, Ding S. 2018. Genetic diversity within grouper species and a method for interspecific hybrid identification using DNA barcoding and RYR3 marker. Mol Phylogenet Evol 121: 46-51. DOI: 10.1016/j.ympev.2017.12.031

Qu M, Zhang X, Ding S-X. 2012 Complete mitochondrial genome of yellow grouper Epinephelus awoara (Perciformes, Epinephelidae). Mitochondrial DNA 23 (6): 432-434. DOI: 10.3109/19401736.2012.710217

Rozas J, Ferrer-Mata A, Sánchez-DelBarrio JC, Guirao-Rico S, Librado P, Ramos-Onsins SE, Sánchez-Gracia A. 2017. DnaSP 6: DNA sequence polymorphism analysis of large data sets. Mol Biol Evol 34 (12): 3299-3302. DOI: 10.1093/molbev/msx248

Song H, Buhay JE, Whiting MF, Crandall KA. 2008. Many species in one: DNA barcoding overestimates the number of species when nuclear mitochondrial pseudogenes are coamplified. PNAS 105 (36): 13486-13491. DOI: 10.1073/pnas.0803076105

Sukandar, Handayani M, Dewi CSU, Harsindhi CJ, Maulana AW, Supriyadi, Bahroni A. 2016. Profile of coastal villages in East Java Province volume III (Madura Islands). Surabaya: Marine, Coastal, and Supervision of the Department of Fisheries and Marine Affairs of East Java Province. [Indonesian] 
Tapilatu RF, Tururaja TS, Sipriyadi, Kusuma AB. 2021. Molecular phylogeny reconstruction of grouper (Serranidae: Epinephelinae) at northern part of Bird's Head Seascape-Papua inferred from COI gene. Fish Aquat Sci 24 (5): 181-190. DOI: 10.47853/FAS.2021.e18

Thompson JD, Higgins DG, Gibson TJ. 1994. CLUSTAL W: Improving the sensitivity of progressive multiple sequence alignment through sequence weighting, position-specific gap penalties and weight matrix choice. Nucleic Acids Res 22 (22): 4673-80. DOI: $10.1093 / \mathrm{nar} / 22.22 .4673$
Trivedi S, Affan R, Abdulrahman A, Ansari A, Dhar B, Mahadani P, Ghosh S. 2014. DNA barcoding of Red Sea Fishes from Saudi Arabia-the first approach. DNA Barcodes 2 (1): 17-20. DOI: 10.2478/dna-2014-0003

Ward R, Zemlak T, Innes B, Last P, Hebert P. 2005. DNA barcoding Australia's fish species. Philos Trans R Soc Lond, B, Biol Sci 360 (1462): 1847-1857. DOI:10.1098/rstb.2005.1716 